\title{
en 643
}

ORNL/TM-5731

\section{Improved Gas Distributor for Coating HTGR Fuel Particles}

\author{
W. J. Lackey \\ D. P. Stinton \\ J. D. Sease
}




\section{DISCLAIMER}

This report was prepared as an account of work sponsored by an agency of the United States Government. Neither the United States Government nor any agency Thereof, nor any of their employees, makes any warranty, express or implied, or assumes any legal liability or responsibility for the accuracy, completeness, or usefulness of any information, apparatus, product, or process disclosed, or represents that its use would not infringe privately owned rights. Reference herein to any specific commercial product, process, or service by trade name, trademark, manufacturer, or otherwise does not necessarily constitute or imply its endorsement, recommendation, or favoring by the United States Government or any agency thereof. The views and opinions of authors expressed herein do not necessarily state or reflect those of the United States Government or any agency thereof. 


\section{DISCLAIMER}

Portions of this document may be illegible in electronic image products. Images are produced from the best available original document. 


\section{Printed in the United States of America. Available from National Technical Information Service}

U.S. Department of Commerce

5285 Port Royal Road, Springfield, Virginia 22161

Price: Printed Copy $\$ 4.00$; Microfiche $\$ 3.00$

This report was prepared as an account of work sponsored by the United States Government. Neither the United States nor the Energy Research and Development Administration/United States Nuclear Regulatory Commission, nor any of their employees, nor any of their contractors, subcontractors, or their employees, makes any warranty, express or implied, or assumes any legal liability or responsibility for the accuracy, completeness or usefulness of any information, apparatus, product or process disclosed, or represents that its use would not infringe privately owned rights. 
ORNL/TM-5731

Distribution

Category UC-77

Contract No. W-7405-eng-26

METALS AND CERAMICS DIVISION

THORIUM UTILIZATION PROGRAM (189a OHO45)

Refabrication Development - Task 300

IMTROVED GAS DISTRIBUTOR FOR COATING HTGR FUEL PARTICLES

W. J. Lackey, D. P. Stinton, and J. D. Sease

Date Published: January 1977

OAK RIDGE NATIONAL LABORATORY

This report was prepared as an account of work sponsored by the United States Government. Neither Research and Deves nor the United Stales Energy their employees, nor any of their contractors, warranty, express or impled, or assimes any legal or usefulness of any information, apparatus, product or

Oak Ridge, Tennessee 37830

process disclosed, or represents that its use would not

Oak Ridge, Tennes
operated by

ÜNION CARBIDE CORPORATION

for the

ENERGY RESEARCH AND DEVELOPMENT ADMINISTRATION

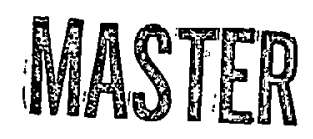


THIS PAGE

\section{WAS INTENTIONALLY LEFT BLANK}


CONTENTS

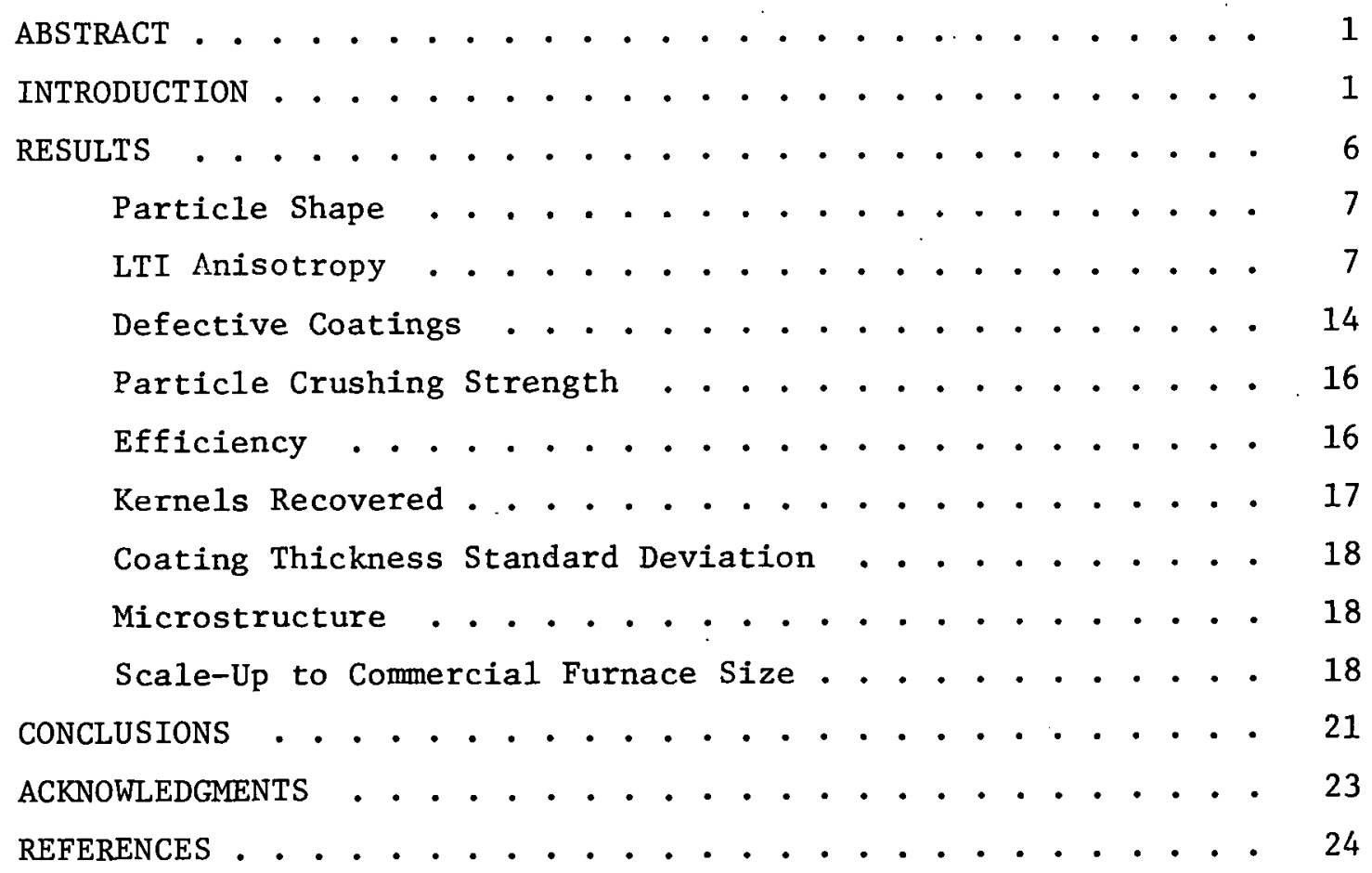




\title{
IMPROVED GAS DISTRIBUTOR FOR COATING HTGR FUEL PARTICLES
}

\author{
W. J. Lackey, D. P. Stinton, and J. D. Sease
}

\section{ABSTRACT}

A new and improved gas distributor was developed for use in coating fuel particles for the HTGR. The coating gas enters the coating furnace through multiple thin regions of a porous plate. This more uniformly disperses the gas and leads to improved coating properties. High-quality carbon and SiC coatings have been deposited with the new distributor in both $13-$ and 24-cm-diam coating furnaces.

\section{INTRODUCTION}

Coatings for thorium- and uranium-bearing fuel particles for HighTemperature Gas-Cooled Reactors consist of chemically vapor deposited carbon and silicon carbide. The coatings provide mechanical strength and retain fission products. Two types of pyrocarbon coatings are used: a low-density buffer and a higher density low-temperature isotropie (LTI) coating. By varying the type of hydrocarbon gas, deposition temperature, flow rate, etc., carbon coatings can be deposited with the desired properties. S1licon carbide coatings are deposited by the decomposition of $\mathrm{CH}_{3} \mathrm{Cl}_{3} \mathrm{Si}$ in the presence of hydrogen. All the coatings are deposited iil a rluidlzed-bed coaring furnace. 1,2

The most important component of the coating furnace is the gas distributor, which brings the coating gases into contact with the fuel particles. The Important criteria to be considered in design of the gas distributor are:

1. The distributor should ideally disperse the gas over the full area of the coating chamber to increase the particle-gas contact area. 
This increases the uniformity of particle motion and the region within which coatings are deposited; it likewise reduces bubble size and violent particle surging.

2. The gas should not be excessively heated during its passage through the distributor. Otherwise it will partially decompose prematurely, causing excessive deposition within or on the distributor.

3. The distributor should be suitably designed and have sufficient mechanical integrity to virtually eliminate loss of particles from the coating chamber.

4. The distributor should provide for rapid and reliable discharge of hot particles from the furnace.

5. The distributor should be simple, inexpensive, reliahle, and easily maintainable.

6. The distributor should be capable of depositing both carbon and SiC coatings of high quality as regards density, preferred orientation, permeability, fráction defective, dnd numerous other coating properties.

The most widely used type of gas distributor is a single-inlet cone or some variation, such as a two-fluid dual concentric inlet cone. Conical gas distributors as seen in Fig. 1(a) have been under development for about 15 years. The cone satisfies the previously mentioned criteria with three exceptions. The first is nonuniform distribution of coating gas over the bed of particles which along with the conical geometry of the coating chamber causes agglomeration of gas bubbles, a slugging bed action, and excessive throwing of particles. Second, particles can escape from the coating chamber through the gas inlet at the apex of the cone. If a malfunction or human error causes the gas fllow to be significantly reduced during coating, heating, or cooling, particles will drain from the furnace. A llird problem ariaca bccaue particles do not always drain properly and as a result back up inside the cone. If this goes unnoticed, pyrophoric material may be exposed to air or remaining particles could contaminate the next coating run. The work area can also become contaminated if particles drain or spill from the cone during maintenance or replacement. 
(a)

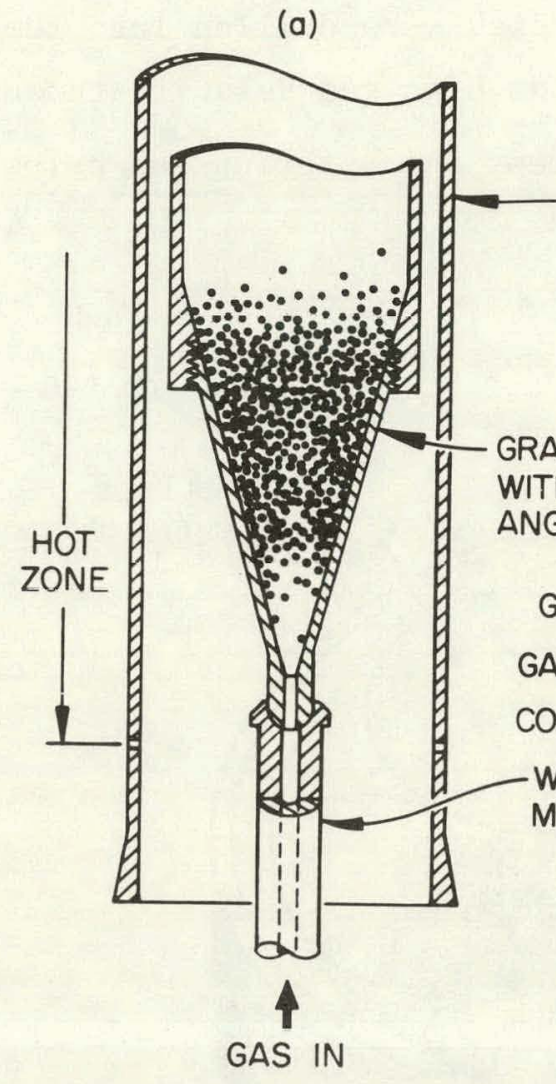

CONICAL GAS DISTRIBUTOR (b)

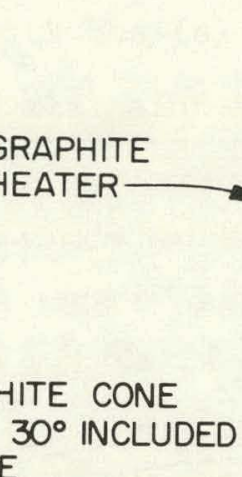

GRAPHITE-

GAS PLENUM COOLING CAVITY WATER-COOLED METAL

Fig. 1. Gas Distributors.
ORNL-DWG 76-13361R I
POROUS CARBON PLATE WITH 8 BLIND HOLES ON 23/4-in. BOLT CIRCLE PLUS ONE IN CENTER

Earlier gas distributors used multiple inlets protruding through either a porous carbon base or through an array of dense carbon cones, ${ }^{3}$ but both approaches suffer from complexity, loss of particles through the multiple inlets, or variation in gas flow from inlet to inlet. Another design uses a uniform thickness of porous carbon as the gas distributor. This works well during the initial portion of the run but soon plugs, beginning at the perimeter, because of insufficient gas velocity within the porous portion of the distributor allows the gas to reach the decomposition temperature range. A variation of this gas distributor has been developed during the past four years at Oak Ridge National Laboratory. ${ }^{4}$ To increase gas velocity, blind holes were drilled into the carbon to allow most of the gas to pass through the thinned regions. This design eliminated plugging but allowed particles 
to stick to the porous carbon between the drilled holes. To minimize particle sticking to the frit, conical blind holes were drilled into the porous carbon as shown in Figs. 1(b) and 2. The high gas velocity through the thinned regions of this blind-hole frit keeps the entering gas below its decomposition temperature.

ORNL-DWG 75-1464

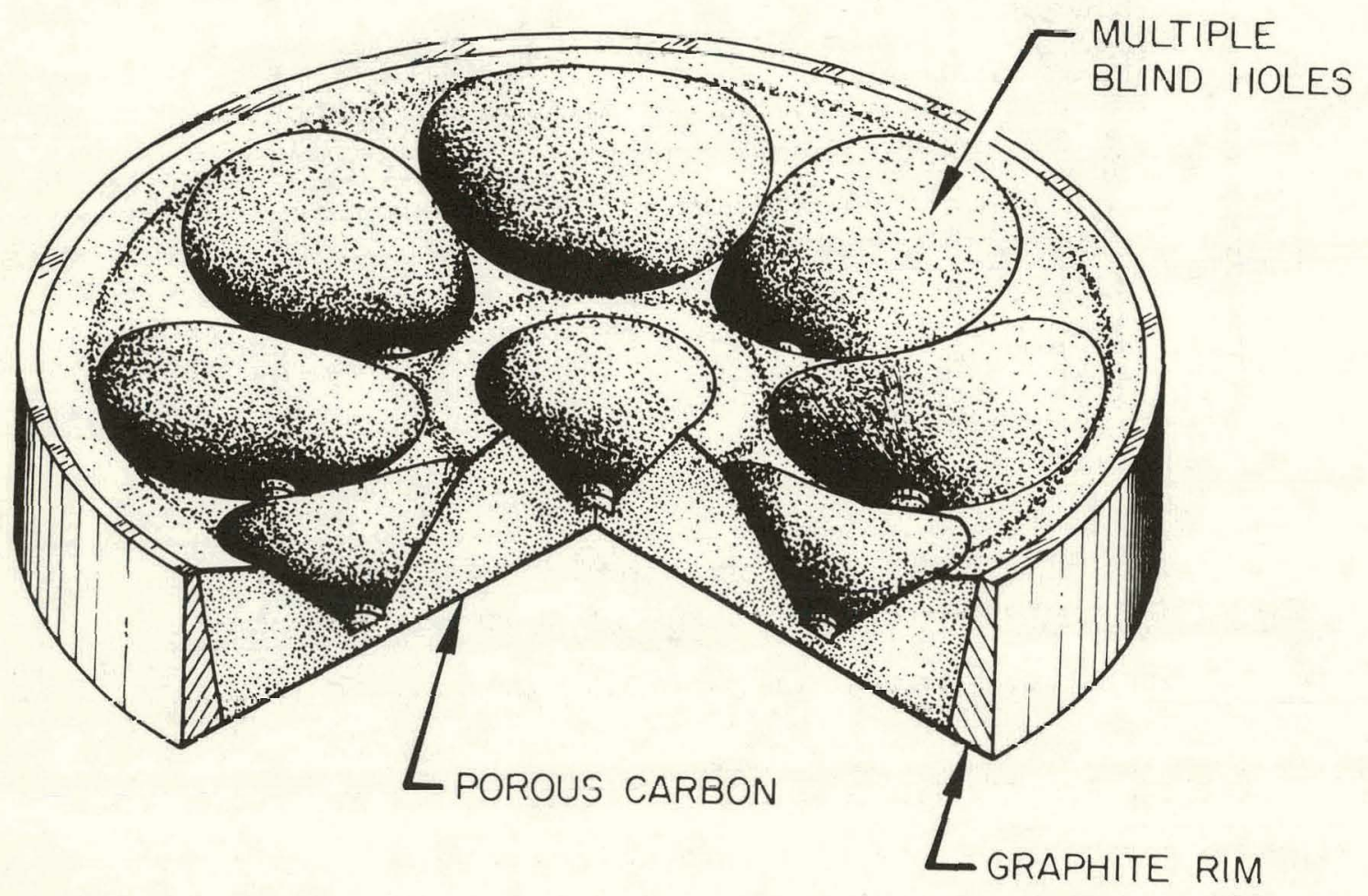

Fig. 2. Frit or Blind Hole Porous Plate Gas Distributor. The porous material is Grade 25 porous carbon available from Union Carbide Corporation.

An advantage of the new frit design is that the porous distrihutor and not the particle bed provides most of the resistance to gas fluw. Therefore, localized variations in the quantity of particles above any particular gas inlet do not significantly alter the flow rate through that inlet.

One disadvantage of the frit is its higher fabrication cost compared with the simplest conical distributors. Both the cone and frit must be maintained after almost every coating run because of deposits on the 
wall of the cone and the top of the frit. However, gas distributor costs are not large when compared with the total cost of fuel fabrication. ${ }^{5}$ For small orders the cost of a single $24-\mathrm{cm}$-diam frit of the most complicated design tested to date is about $\$ 50$, including the cost of materials as well as machining. Conservatively assuming that $3 \mathrm{~kg}$ of uranium can be processed per frit, we find then that the frit cost is only about $3 \%$ of the total cost involved in the fabrication of fresh fuel and about $1 \%$ of the cost for fabrication of recycle fuel. The costs for conical distributors may be about half that of the frit. However, the frit cost is not an overriding concern.

Another potential disadvantage of using the frit is the additional mechanical equipment necessary to unload a batch of particles. Equipment must be provided to lower the coating chamber from the furnace and unload the particles onto a scalping screen, which removes oversize debris that would otherwise interfere with pneumatic particle transfer. Figure 3 shows the coating furnace loop required when a frit is used in a remote facility, such as a hot cell, which is required for recycle fuel. Similar

FROM

ORNL-DWG 75-6967

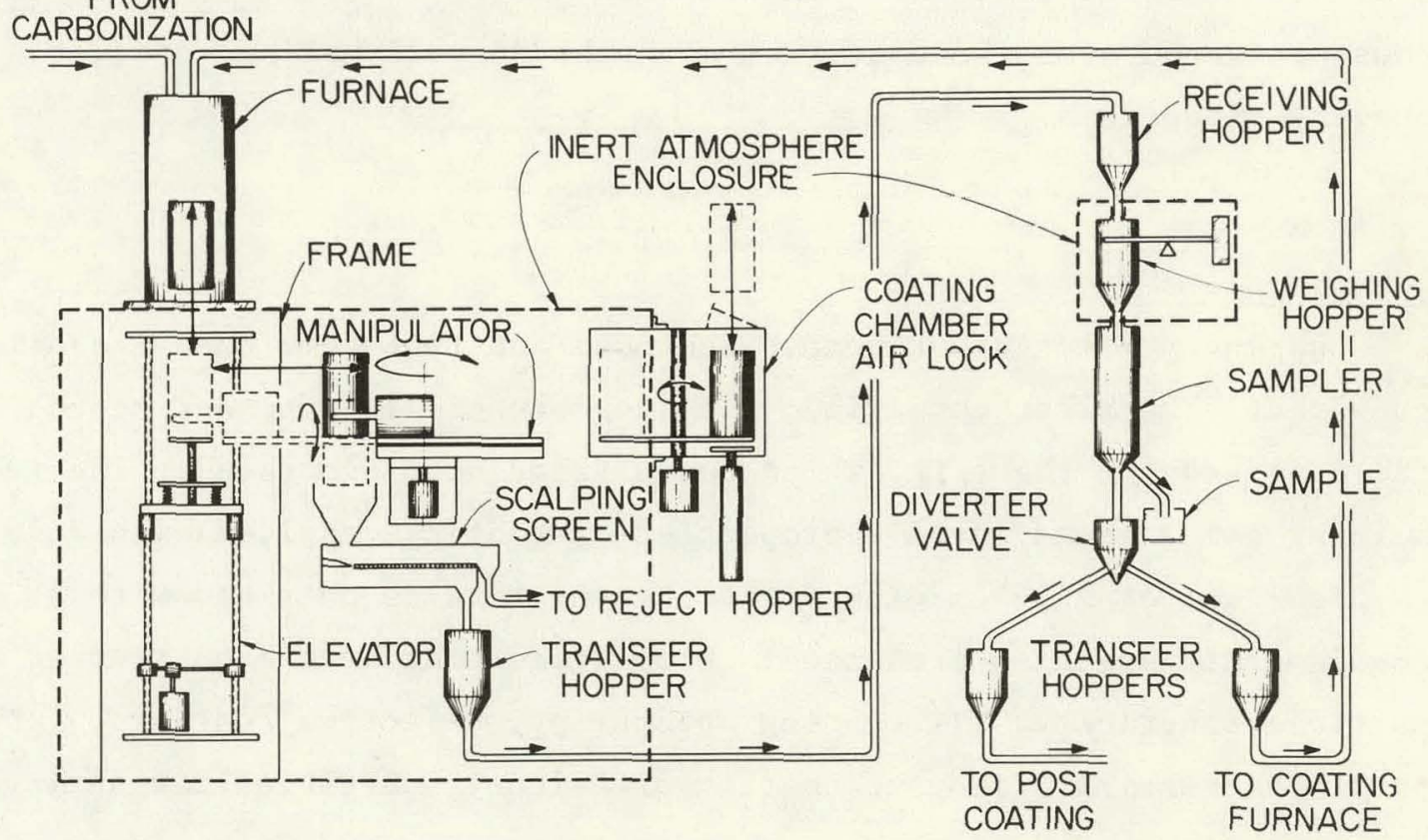

Fig. 3. Remote Coating Furnace Loop. 
or perhaps the same equipment would probably be preferred for a fresh fuel plant. The majority of equipment (i.e., hoppers, sampler, weigher, scalping screen, and transfer lines) are required for either the cone or the frit. If a cone were used, one might expect that the inertatmosphere enclosure would not be necessary because pyrophoric kernels could be drained through the hole in the cone directly into an inertatmosphere container. However, the bottom of the furnace would likely be opened frequently for cone maintenance or replacement, and an inertatmosphere enclosure around the furnare base might be desired to climinate leakage of air into the open furnace. Also an inert-atmosphere enclosure might be necessary for off-normal situations where pyrophoric material fails to completely drain from the cone. The manipulator and elevator might also be needed for use with a conical distributor since some means is required for handling the cone and raising it into the furnace. Even with any added complexity of unloading particles when the frit is used, we believe that the frit system is mechanically more reliable and provides better material accountability than the system used with a cone. Since we will show that the coatings deposited with the frit are superior to those obtained when a rone is used, the frit is thus preferred over the cone from both the operational and product yualily viewpoints.

\section{RESULTS}

Durlng the last four years, the cone and frit have been extensive1y compared. 'The first comparison was the mechanical equipment needed for the cone and for the frit, which has already been discussed. The remaining comparisons involve properties of coatings applied with a 13cm-diam cone or a 13-cm-diam frit. Recent results nhtained with a 24$\mathrm{cm}$-diam frit are also presented. Properties that have been studied are particle sphericity, LTI coating anisotropy, defective coatings, wholeparticle crushing strength, coating efficiency, particle loss during coating, standard deviation of coating thickness, and microstructure. 


\section{Particle Shape}

Coated particles ideally should be nearly spherical to perform properly during irradiation. Particles become faceted during coating because carbon is deposited unevenly around the particle. An index termed "shape ratio" has been developed to measure the sphericity of coated particles. ${ }^{6}$ The shape ratio is obtained for each particle by dividing the coating thickness on one side of a particle by the thickness on the opposite side. The particle shape for a batch is characterized by averaging 50 individual ratios. Figure 4 shows how the appearance of particles changes for shape ratios from 1.05 to 1.21 .

A statistically designed experiment was conducted to determine how particle shape was influenced by the major process variables and by the type of gas distributor used. Forty-five coating runs were conducted with a 13-cm-diam coating furnace with a $30^{\circ}$-single-inlet conical gas distributor. Eight additional coating runs were made with various designs of the porous plate gas distributor. In each case the product was Biso-coated $\mathrm{ThO}_{2}$. This experiment ${ }^{6}$ showed that shape ratio was a function of coating rate and temperature, as seen in Fig. 5. The curves were fit by a multiple regression analysis of the 45 coating runs made with the cone. The shape ratios of coating runs made with the frit at $1375^{\circ} \mathrm{C}$ are also shown on this graph, and these data points should be compared with the curve labeled $1375^{\circ} \mathrm{C}$. The frit produced coatings with shape ratios lower than any of the similar runs using the conical gas distributor. The shape ratio ranged from 1.06 to 1.09 for the porous plate runs compared with 1.13 to 1.16 for the similar conical runs. The 95\% confidence intervals for the mean shape ratio for particles coated by use of the porous plate and the cone do not overlap. Similar results were obtained for Triso-coated fissile particles. ${ }^{7}$

\section{LTI Anisotropy}

During irradiation graphitic materials undergo considerable anisotropic dimensional changes. They expand in the $c$ direction and contract 


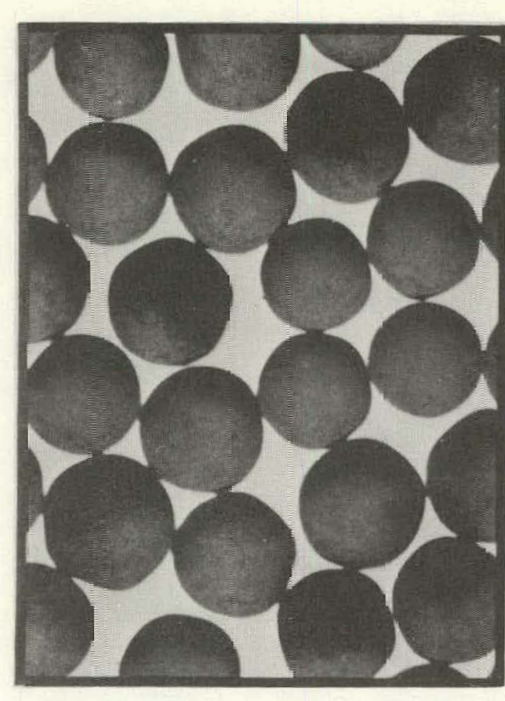

1.054

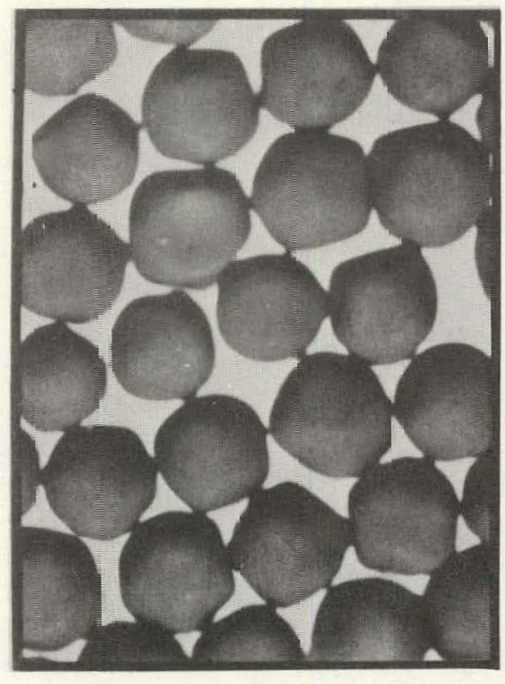

1.141

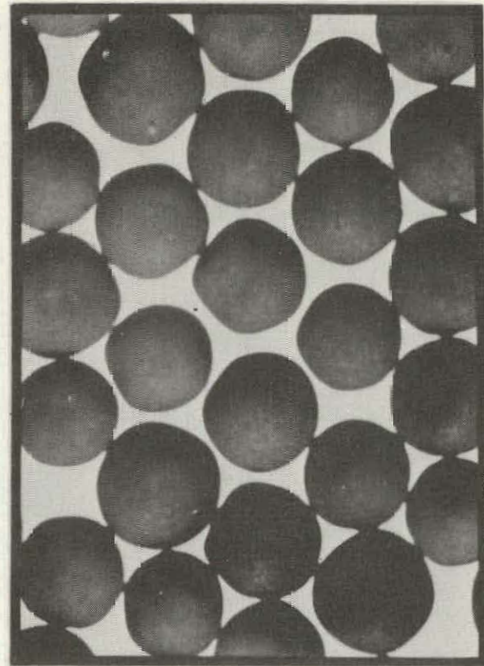

1.077

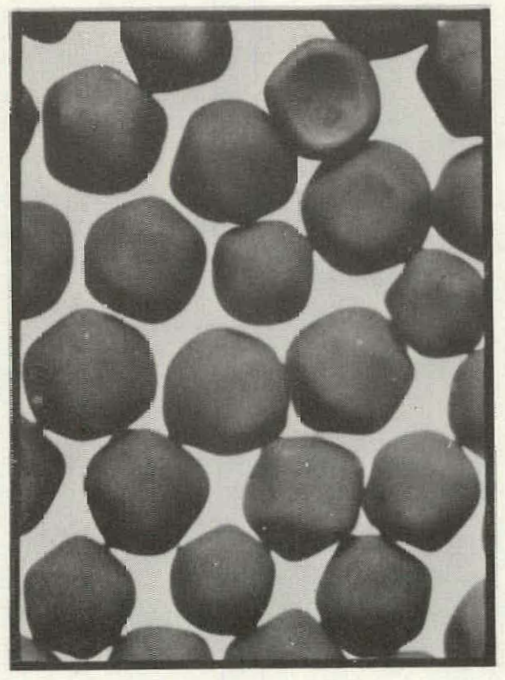

1.154

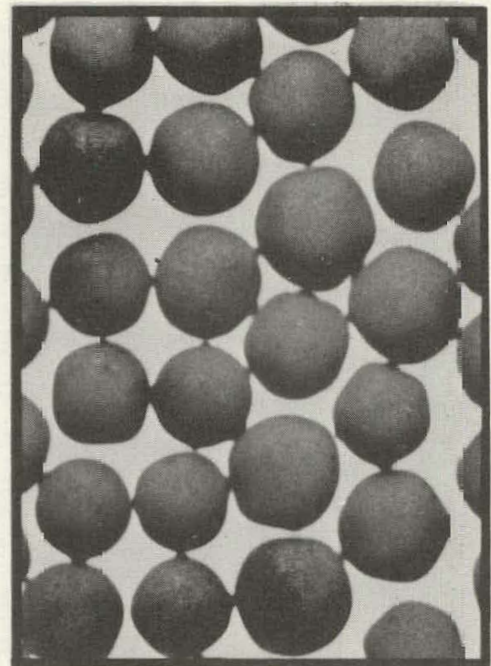

1.096

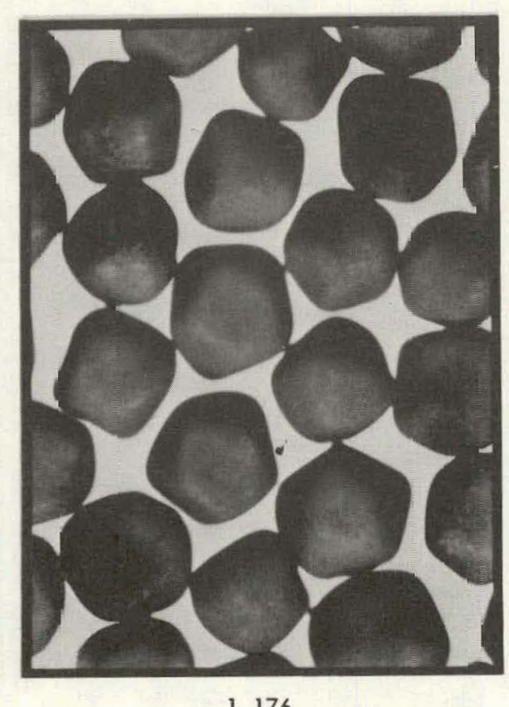

1.176

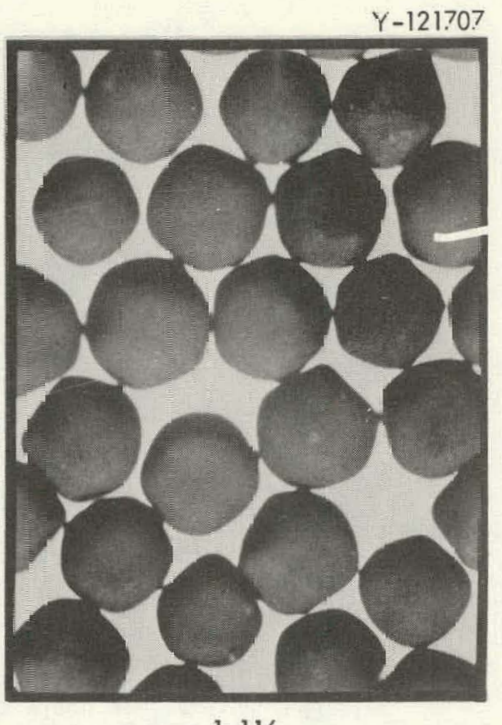

1.116

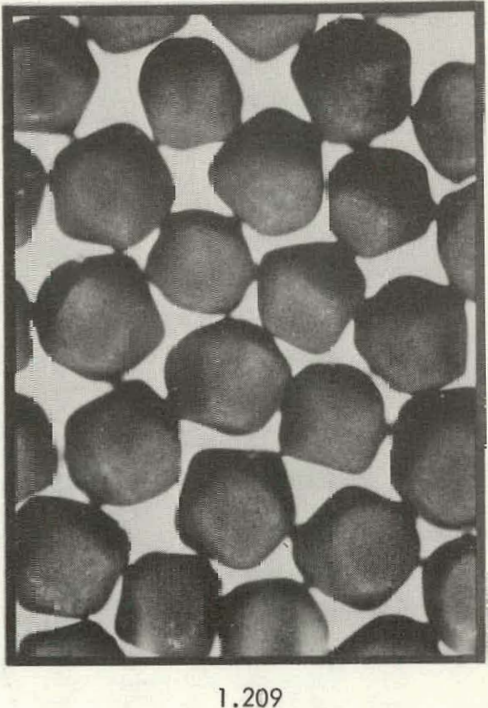

Fig. 4. Comparison of ITI Shape Ratio with Macrographs of Eiso-Coazed Particles. 


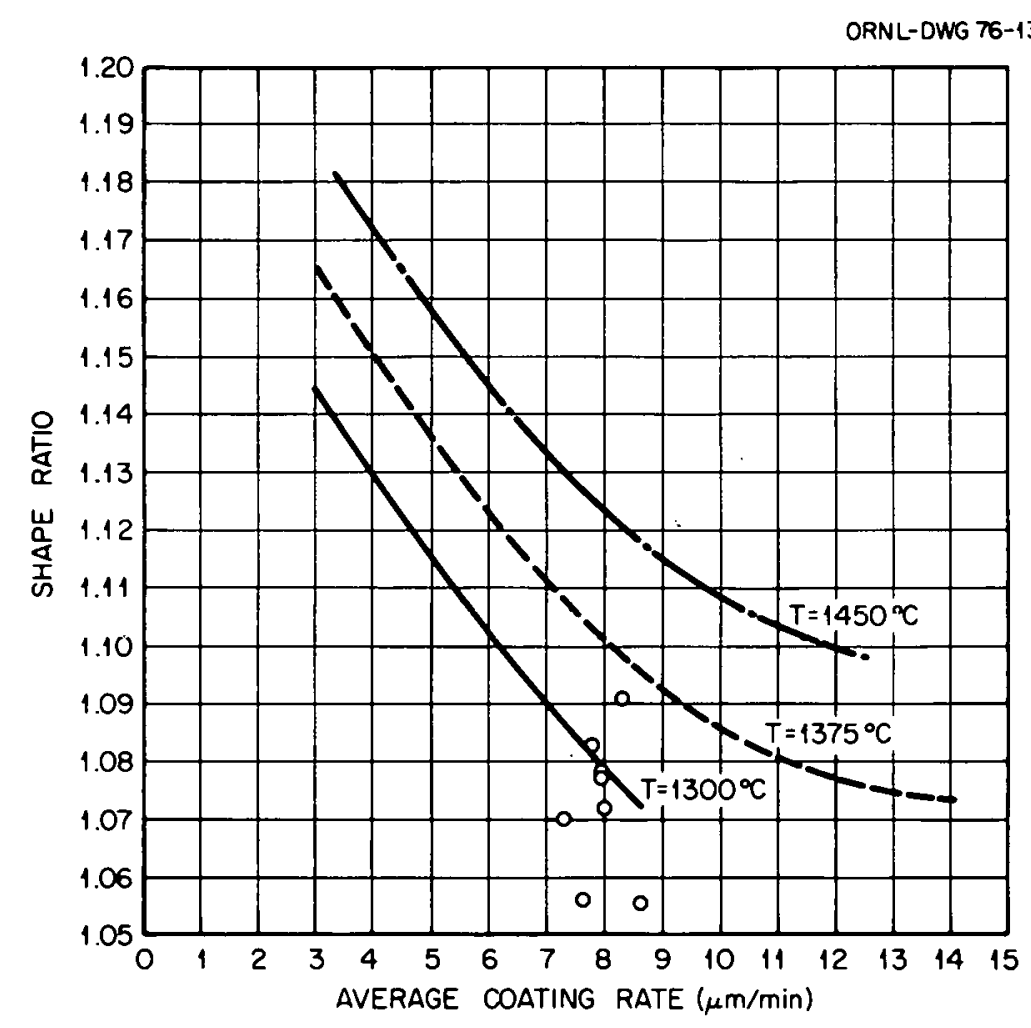

Fig. 5. Influence of Coating Rate, Temperature, and Gas Distributor Type on LTI Faceting. The curves are from a multiple regression analysis of 45 coating runs made with a conical gas distributor. The data points are for runs made at $1375^{\circ} \mathrm{C}$ with several blind-hole frit designs.

in the orthoganal directions. The LTI layers of coated fuel particles must be quite isotropic to avoid the generation of high stresses during irradiation.

Particles from the experiment on LTI faceting described above were also used to examine the effect that coating variables and gas distributor type have on the anisotropy of LTI coatings. The Bacon anisotropy factor as determined optically $\left(\mathrm{BAF}_{\mathrm{O}}\right.$ ) was measured by General Atomic Company for all the coatings. The $\mathrm{BAF}_{0}$ depended on the coating rate, in agreement with other investigations. ${ }^{8}$ Anisotropy values for coatings applied with the cone and frit are shown in Fig. 6. The BAF。 values of all the coatings applied with the frit are lower than any values for coatings applied with the cone. The anisotropy difference is more striking if one compares coatings deposited at the same deposition 


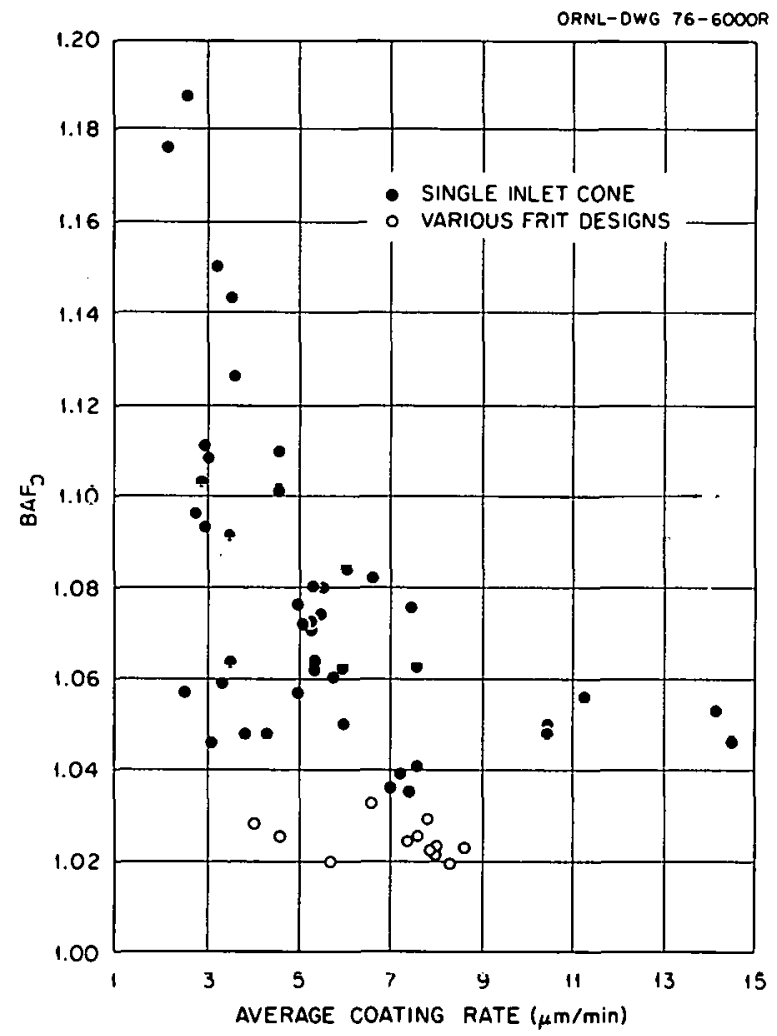

Fig. 6. Influence of Coating Rate on BAF ${ }_{0}$ for LTI Coatings Deposited with a $13-\mathrm{cm}-\mathrm{diam}$ Cone or Frit.

temperature and rate. The curves of Fig. 7 were found by a multiple regression analysis for the 45 coating runs made with the cone. The lines of Fig. 7 show that a large amount of the scatter in the data of Fig. 6 for the cone runs is accounted for by the effect of deposition temperature. The deposition temperature effect was shown to be statistically significant at the $99 \%$ confidence level. The points in Fig. 7 are for coatings deposited at $1375^{\circ} \mathrm{C}$ by use of the frit. Comparison of these points with the line labeled $1.375^{\circ} \mathrm{C}$ in Fig, 7 shows that the frit produces coatings having $\mathrm{BAF}_{\mathrm{o}}$ values about 0.02 to 0.04 units lower than coatings similarly deposited with a cone. This is potentially a significant effect when viewed in terms of the ability of the coatings to survive irradiation to high neutron fluences. The reason for the lower BAF values obtained with the frit is unknown but may be related to the more uniform distribution of coating gas. 


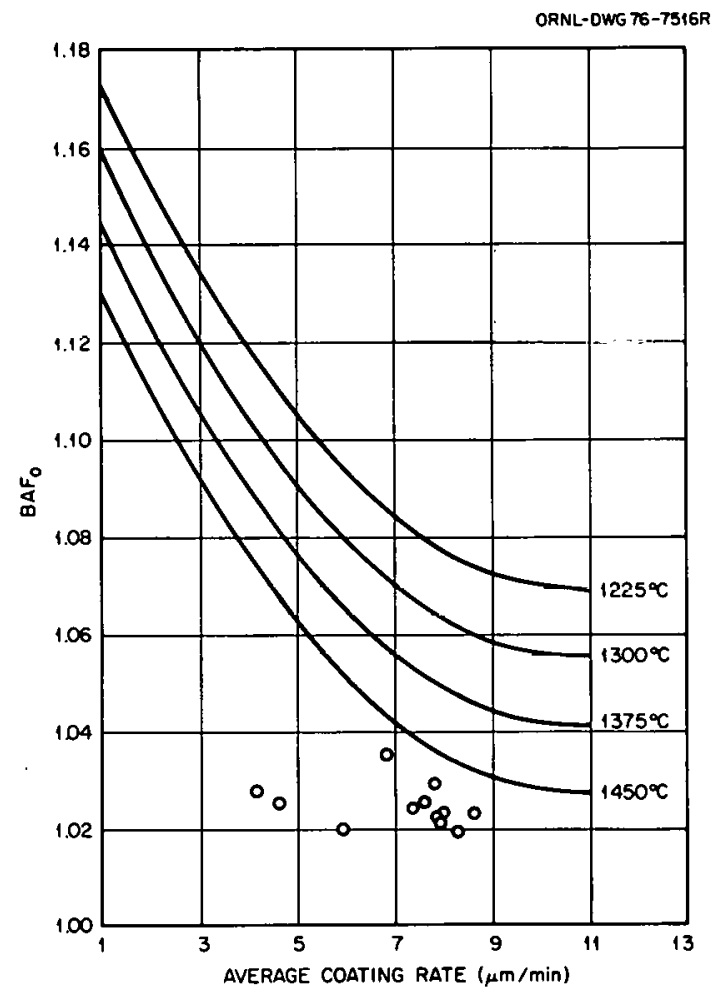

Fig. 7. Correlation of $\mathrm{BAF}_{0}$ with Coating Rate, Temperature, and Gas Distributor. The curves are from a multiple regression analysis of 45 coating runs made with a conical gas distributor. The data points are for runs made at $1375^{\circ} \mathrm{C}$ with several blind-hole frit designs. The curves and points are for a propylene flow rate of 0.17 std liter/sec. (3.6 scfm).

Perhaps a more important factor than the average $\mathrm{BAF}_{0}$ value for a particle batch is the fraction of the particles that have a BAF。 value greater than some critical value above which an appreciable fraction of coatings would fail during irradiation. Thus the particle-to-particle variation in $\mathrm{BAF}_{0}$ within the batch as measured by the standard deviation is important. Particles coated in a 13-cm-diam cone under typical coating conditions had a standard deviation of 0.011 , while particles coated with a 13- or 24-cm-diam frit had a standard deviation of about 0.004 . The lower standard deviation for particles coated with the frit implies greater uniformity of the coating conditions from place to place within the fluidized bed. Also, two factors contribute to lower standard deviations for particles coated with the frit. For a given batch of particles, typically the $\mathrm{BAF}_{\mathrm{o}}$ values for individual particles show a negative correlation with coating thickness (i.e., low $\mathrm{BAF}_{\mathrm{o}}$ values are observed for 
particles having thick coatings). Similarly, for a given particle the $B A F$ varies from point to point around the particle depending on the localized value of coating thickness (i.e., thick portions of the coating tend to have low BAF, values and thin portions high values). The effects of both the particle-to-particle variation in thickness and the within-particle thickness variation contribute to lower standard deviations for particles coated with the frit since these variations in thickness are less pronounced.

For both the cone and frit, the within-batch standard deviation of $\mathrm{BAF}_{0}$ is correlated with the average $\mathrm{BAF}_{0}$ for the batch; standard deviation decreases with decreasing values of mean $B_{0}$, as shown in Fig. 8 . Note that coatings deposited with the 24-cm-diam frit have low values for both the mean $\mathrm{BAF}_{0}$ and the standard deviation of $\mathrm{BAF}_{0}$.

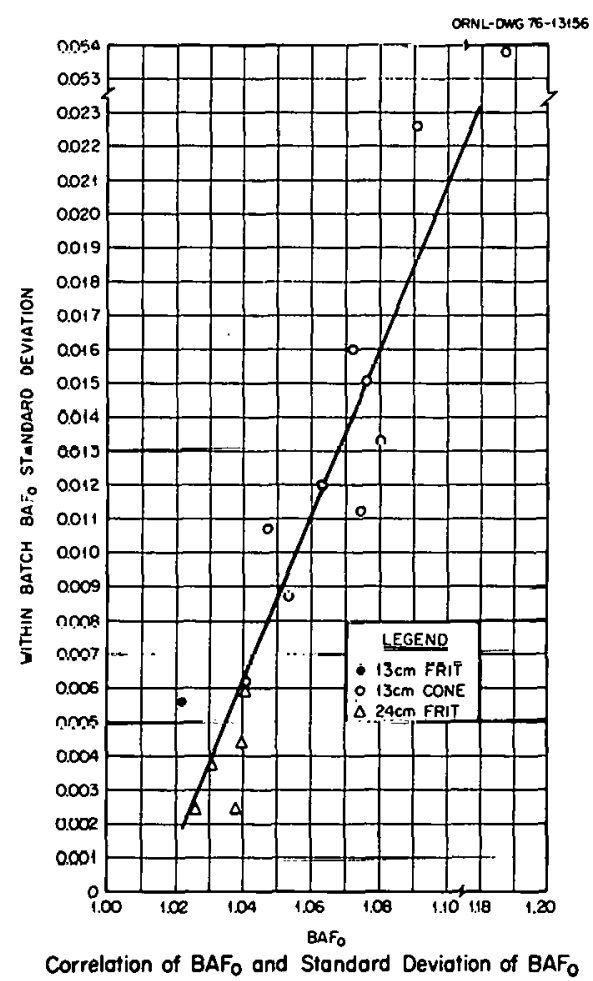

Fig. 8. Correlation of $\mathrm{BAF}_{\mathrm{o}}$ and Standard Deviation of $\mathrm{BAF}_{0} \cdot$ Note the breaks in the scales. 
The importance of the particle-to-particle variation in $\mathrm{BAF}_{0}$ is shown in Fig. 9. Here the within-batch distribution of BAF values is given for typical frit and cone batches. For the frit batch, note that only 0.6 and $0.01 \%$ of the particles have $\mathrm{BAF}_{0}$ values that exceed 1.04 and 1.045 , respectively. In comparison, about $3 \%$ of the particles coated

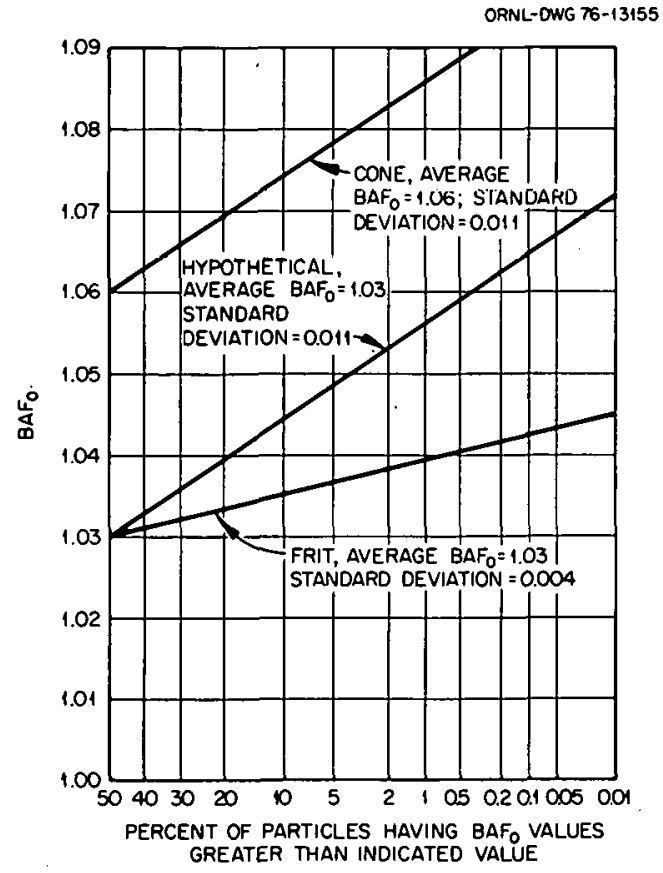

Fig. 9. Particle-to-Particle Variation in LTI Anisotropy.

with a cone have $\mathrm{BAF}_{0}$ values exceeding 1.08. The line in Fig. 9 labeled "hypothetical" shows the importance of standard deviation. For this line, the average $\mathrm{BAF}_{\mathrm{o}}$ value is low (1.03), but because of the high standard deviation (0.011) the fraction of particles having high BAF, values is much larger than for the particles coated with the frit.

Excessive variation of $\mathrm{BAF}_{0}$ through the coating within a given particle could generate stress within the LTI coating as dimensions change during irradiation. The data of Fig. 10 show that such variation need not be excessive. The figure shows the radial variation in $\mathrm{BAF}_{0}$ across the LTI coating for three randomly chosen Biso-coated $\mathrm{Th}_{2}$ particles. The coatings had been deposited with a 24-cm-diam frit and a constant flow of diluted propylene. Two opposing effects were likely 


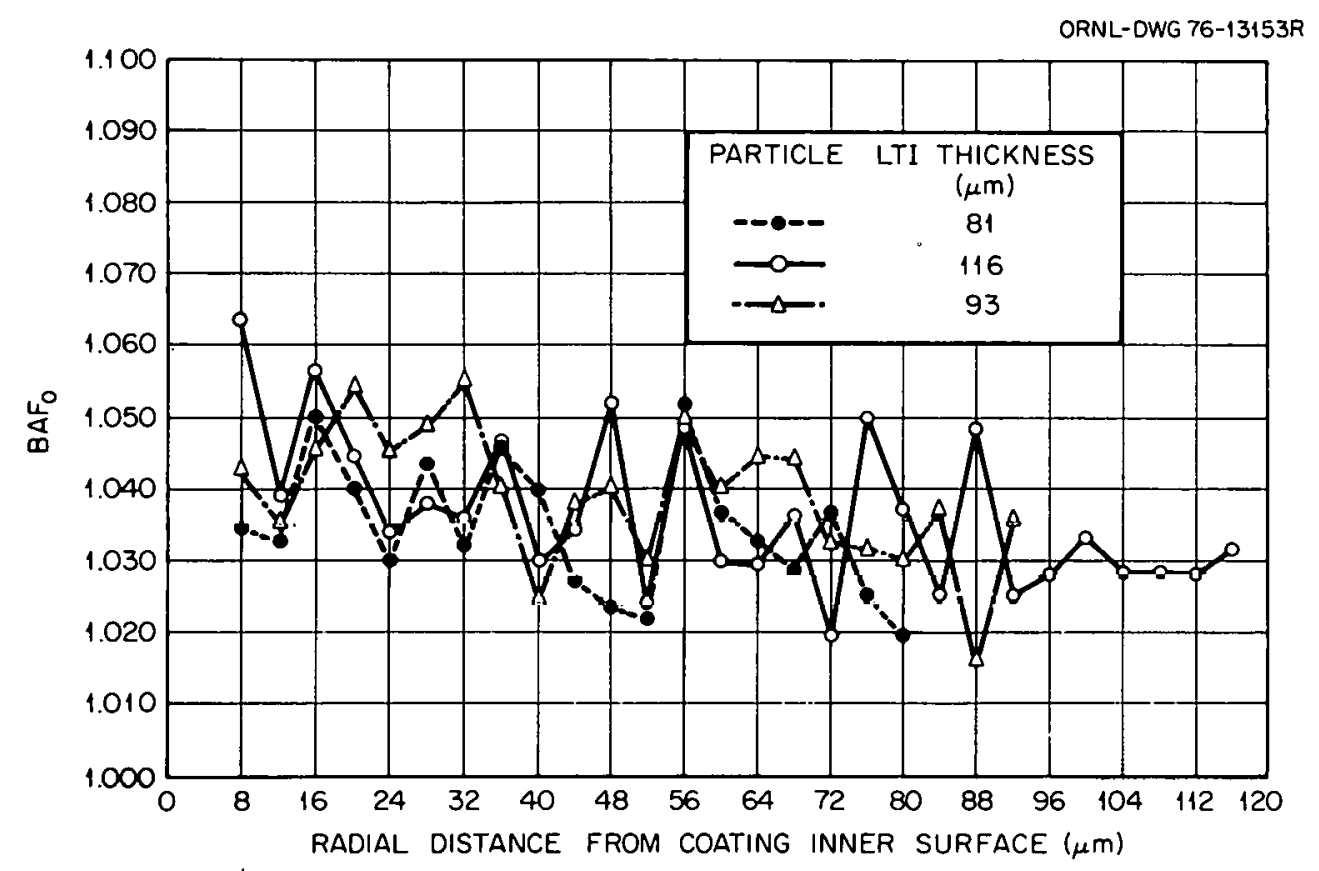

Fig. 10 Within-Particle Variation in LTI Anisotropy.

present: (1) a tendency for the $\mathrm{BAF}_{0}$ to increase with increasing thickness because of a decrease in the deposition rate as the surface area of the particles increased and (2) a tendency for the $\mathrm{BAF}$ to decrease with increasing radial distance since the coating furnace temperature during all but the initial portion of the run was increasing with time. Initially the temperature suddenly dropped because of the cooling effect of propylene decomposition then gradually increased to the set point as a result of a higher power input to the furnace heater. Apparently the two effects nearly cancelled since the net result was only a slight decrease in $\mathrm{BAF}_{\mathrm{o}}$ with location.

\section{Defective Coatings}

The fraction of particles that are defective is determined ${ }^{9}$ by leaching with gaseous chlorine at $1500^{\circ} \mathrm{C}$ for $2 \mathrm{hr}$. A Biso-coated particle is said to be defective if the LTI layer is either cracked or permeable. In a previous study ${ }^{10}$ with Biso-coated $\mathrm{ThO}_{2}$, the fraction defective, as shown in Fig. 11, depended on LTI thickness, coating gas dilution, and whether the particles were annealed or not. Each line is a 


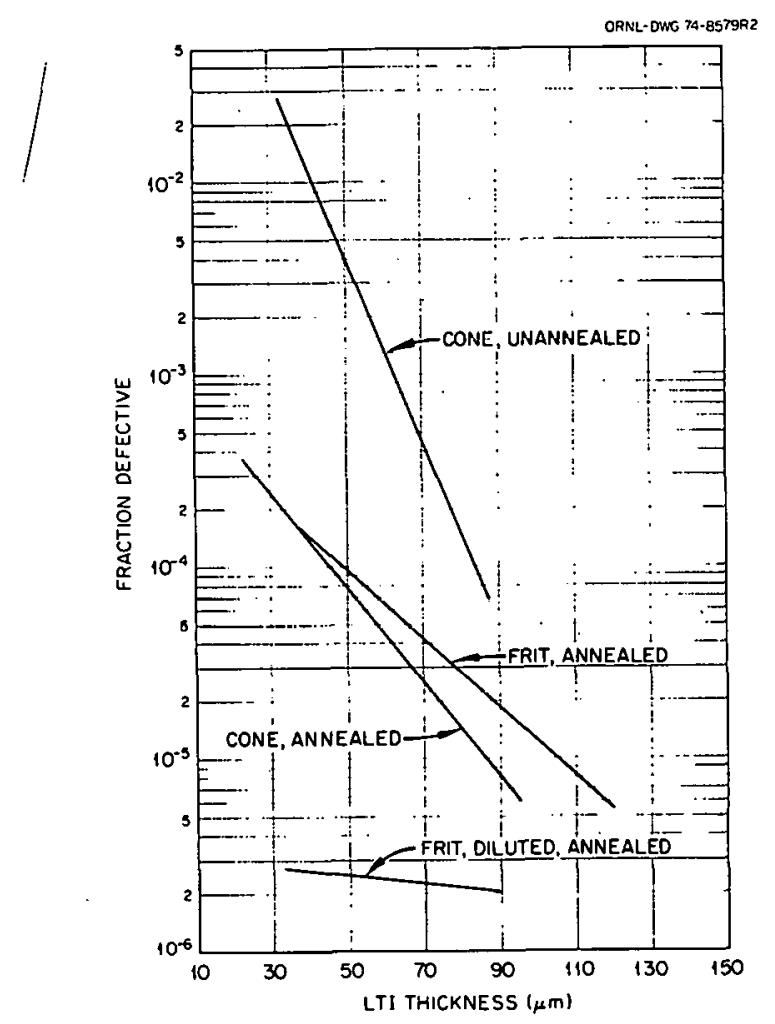

Fig. 11. Effect of Coating Thickness and In-Place Annealing on AsCoated Defective Particle Fraction for Biso-Coated $\mathrm{ThO}_{2}$.

least squares fit of 10 to 50 different coating runs. Unannealed coatings applied with the cone onto buffer-coated thoria yield high defective fractions because stresses generated during coating deposition cause many coatings to crack when subjected to additional stresses during cooling. Cracked coatings are eliminated by annealing before cooling from the coating temperature, and thus for the two lines in the center of Fig. 11, permeable coatings account for the observed defective particles; the slightly higher defective fraction for the frit is the result of either scatter in the data or the use of higher deposition rates for the particles coated with the frit.

Recently unannealed LTI coatings were applied with the 13- and 24$\mathrm{cm}$-diam frits. The results indicate that these coatings do not crack on cooling, contrary to results obtained with the $13-\mathrm{cm}-\mathrm{diam}$ cone. This 
indicates that the frit produces coatings with lower stresses than the cone, perhaps because more uniform deposition conditions yield less radial variation in the properties of the coating.

The fraction of SiC coatings that are cracked is of great importance as regards fission product release from fissile fuel particles. An extensive amount of data shows that the SiC defective fraction is less than the target value of $1 \times 10^{-4}$ for coatings deposited with a 13-cm-diam frit. Limited comparisons indicate that the defective fraction is less than that obtainable with a cone. The defective fraction for the one $\mathrm{SiC}$ run made with a $24-\mathrm{cm}$-diam frit was $3 \times 10^{-5}$.

\section{Particle Crushing Strength}

Whole-particle crushing strength has been studied for Biso and Triso coatings deposited with either the cone or the frit. 12 Typically, gas distributor type does not significantly influence crushing strength of Biso-coated particles. Triso-coated particles annealed at the conditions used for fuel rod annealing (i.e., $1800^{\circ} \mathrm{C}$ for $30 \mathrm{~min}$ ) have higher crushing strengths when coated with the frit rather than the cone. 11

\section{Efficiency}

Cuating efficiency (i.e., the percent of the input carbon that ends up as coating on the particles) is of interest. Low efficiency complicates furnace effluent handling, wastes cnating gas, and increases the run time. Coating efficiency depends on coating conditions but is ronsistently higher for the frit than the cone. The higher efficiency is likely the result of improved gas-solid contact. During buffer coating the efficiency is typically $60 \%$ for the frit and about $50 \%$ for the cone. The efficiency is also higher with the frit for the LTI coating process, as shown in Fig. 12. In this comparison, the coating conditions were constant and only the duration of the run was varied.

Very high coating efficiencies were obtained with the $24-\mathrm{cm}-\mathrm{diam}$ frit. Typically, the buffer and LTI coating efficiencies were 70 and $50-65 \%$, respectively. 


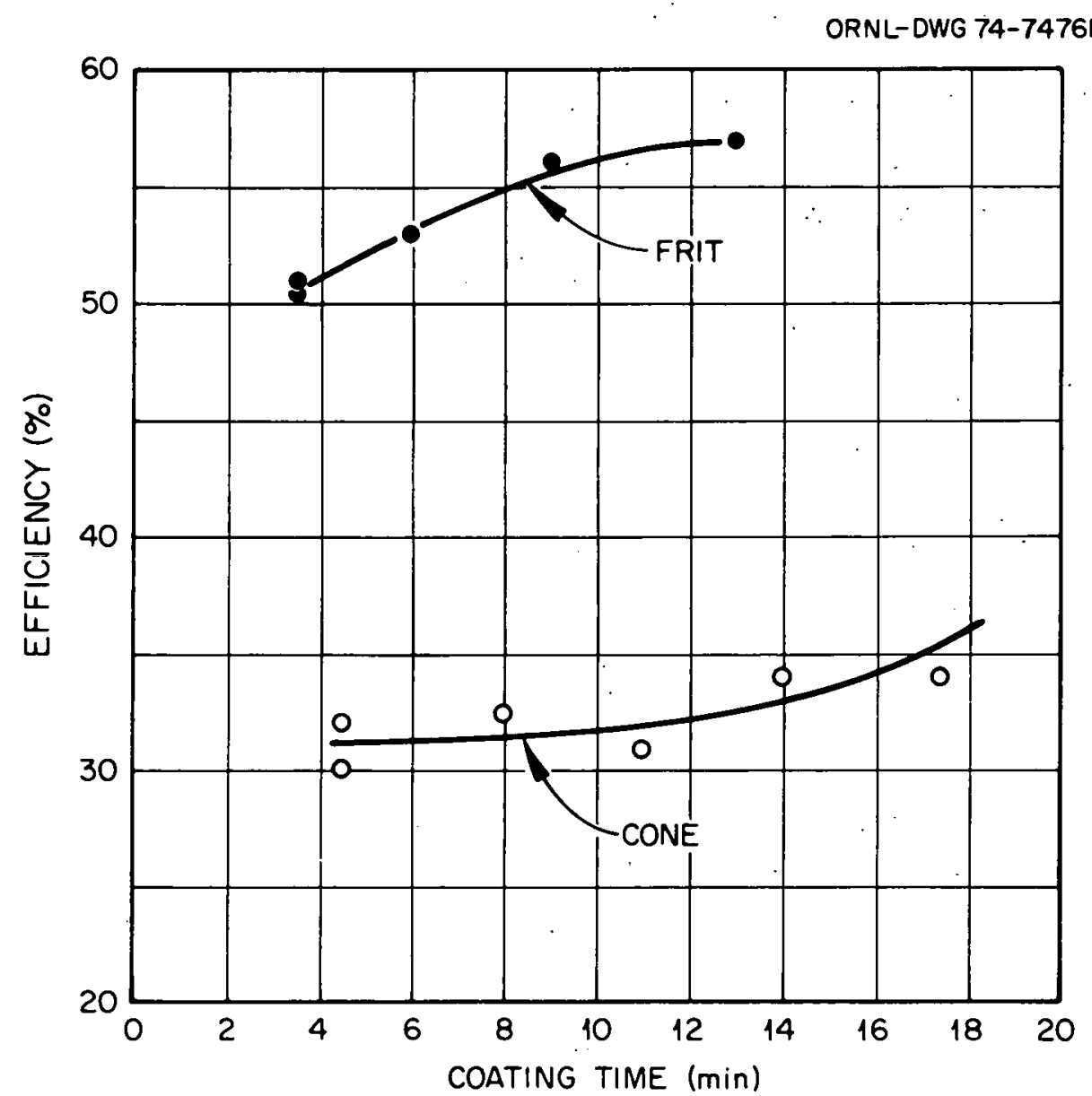

Fig. 12. Comparison of Cone and Frit Coating Efficiency for the LTI Coating Process in a 13-cm-diam Furnace.

\section{Kernels Recovered}

The number of particles "lost" during coating by carry-over into the gas exhaust system or sticking to furnace components must be kept to a minimum. The loss depends on furnace height, gas flow rate, quantity of particles being coated, etc. Accurate measurements are difficult to make, but a large amount of data indicates the loss for the cone and frit in our 13-cm-diam furnace to be less than $1 \%$. There is an indication that the totai loss is less for the frit. This is to be expected since, although more particles adhere to the frit than to the cone, the uniform dispersion of gas obtained with the frit results in less violent eruptions of the particle bed. Observations of hot fluidIzed beds show less throwing of particles with the frit. 
Coating Thickness Standard Deviation

Within-batch particle-to-particle variation in coating thickness is important since particles having a coating layer thinner than some critical value are more likely to fail during irradiation. For the buffer coating process, the coating thickness variation is practically the same for the cone and frit. For the LTI coating process less variation in coating thickness is observed for particles coated with the frit. Thickness standard deviation values depend on a number of process and particle design variables, but typical values for the relative standard deviation for LTI thickness for particles coated in a 13-cm-diam furnace are $9 \%$ for the cone and $7 \%$ for the frit.

\section{Microstructure}

The LTI coatings deposited with a frit have a more uniform microstructural appearance than coatings deposited with a cone, as is evident in Figs. 13 and 14. When a polished surface is viewed with bright-field illumination at 100 to $500 \times$ frit-deposited coatings show noticeably less tendency for porcs or soot inclusions to preferentially align to yield an onion-peel structure. This should result in less tendency for coatings deposited with the frit to delaminate and fail as a result of irradiation-induced dimensional changes. The more uniform structure obtained with the frit is likely the result of more uniform deposition conditions.

\section{Scale-Up to Commercial Furnace Size}

Coating furnaces for commercial operations are expected to be about 24-cill In dlamble. Althuuyli a labge awounl of dala showed the frit rype. of gas distributor to be preferable for 13-cm-diam furnaces, it was not known whether the frit could be successfully scaled to $24-\mathrm{cm}$-diam. The porous carbon portion of the gas distributor is not strong and thus large frits might not withstand the load of particles above them or the force exerted by the coating gas supply below them. To answer the scaleup question, four frit designs were recently tested in a 24-cm-diam 

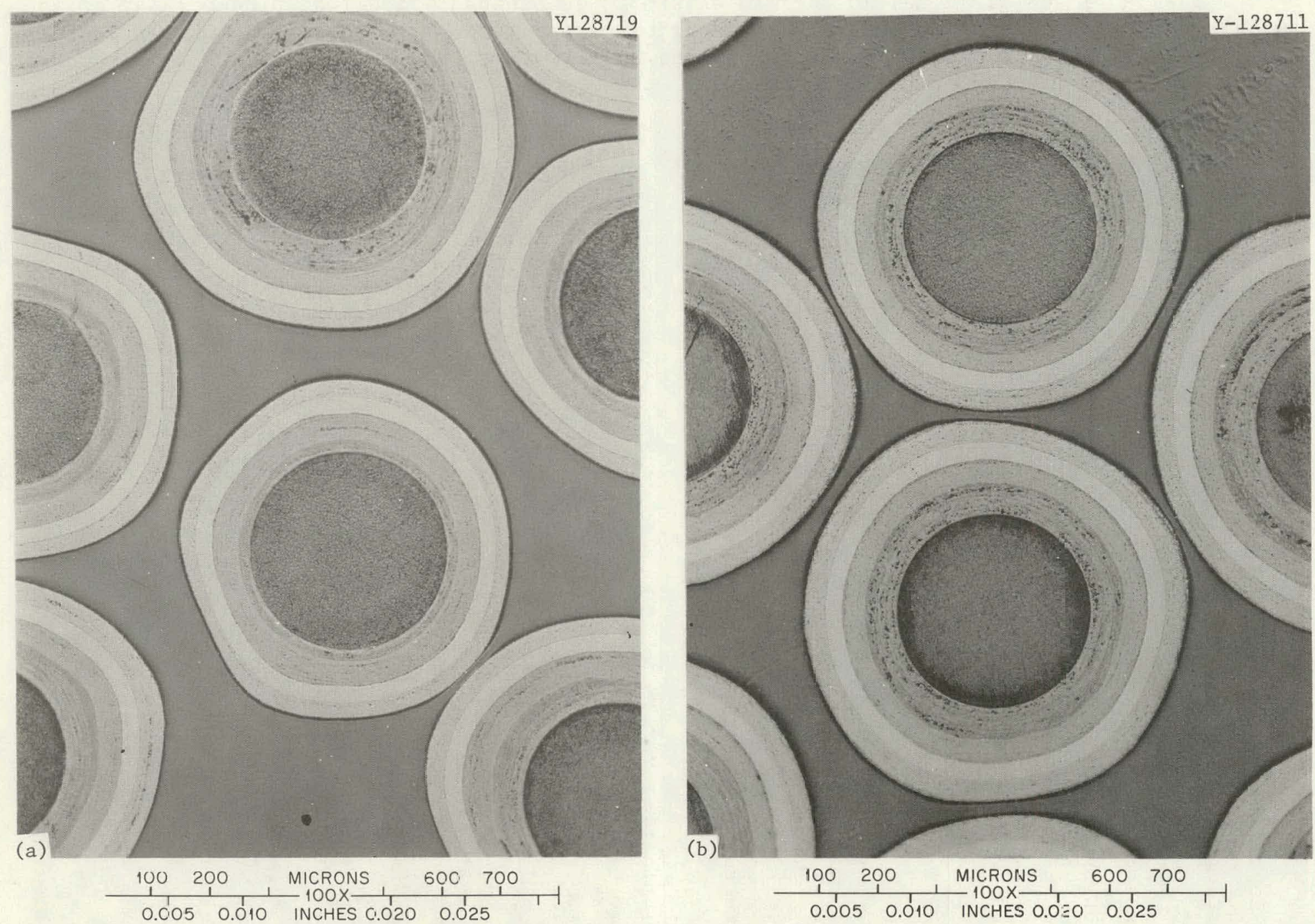

Fig. 13. Comparison of the Microstructure of Coatings Deposited with (a) Cone and (b) Frit. In both cases the particles are of the Triso-coated fissile type. 

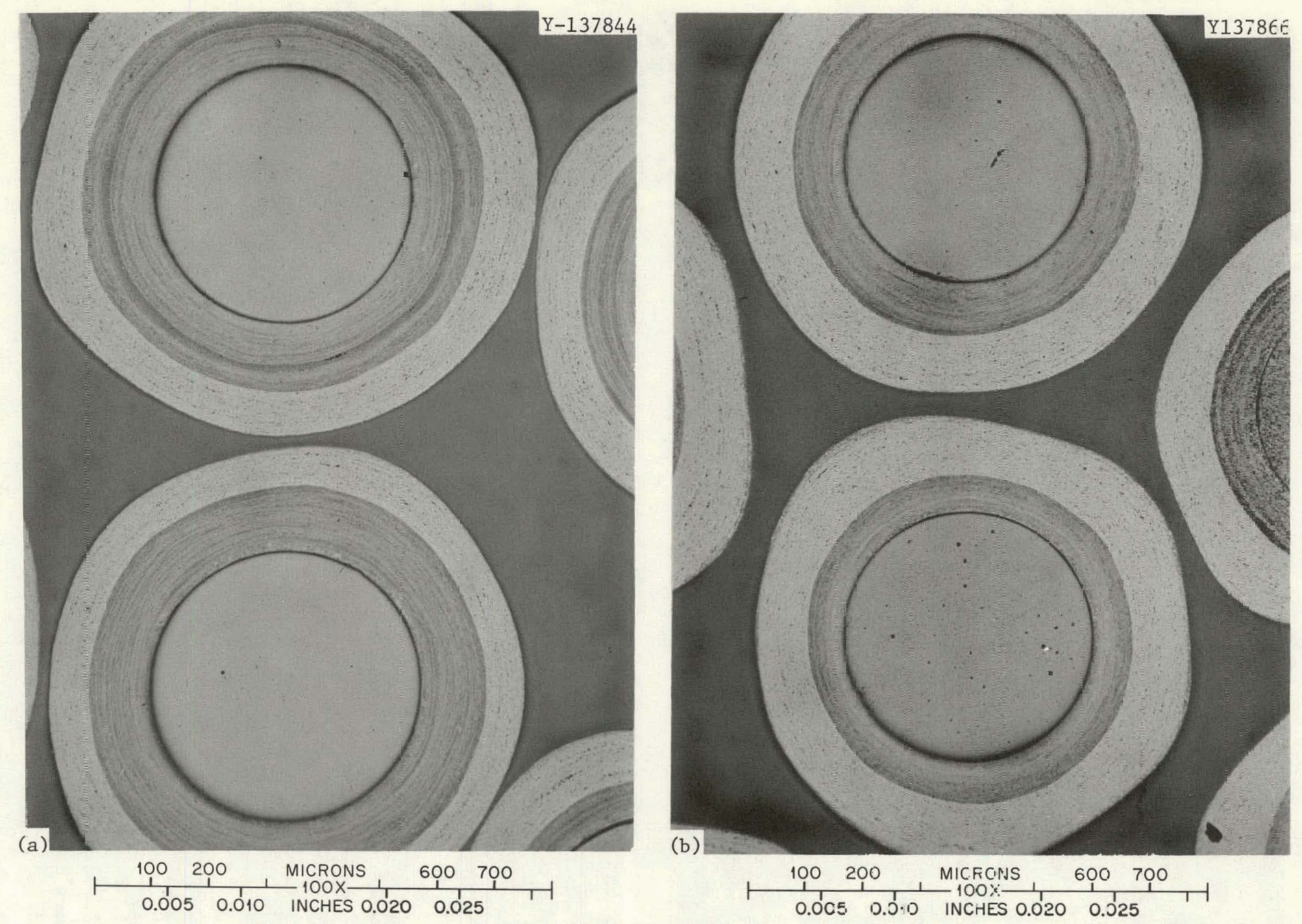

Fig. 14. Biso-Coated $\mathrm{ThO}_{2}$ Prepared with the 24-cm-diam Frit having 25 Holes. (a) LTI deposited fron $\mathrm{C}_{3} \mathrm{H}_{6}$. (b) LTI deposited from mixture of $\mathrm{C}_{2} \mathrm{H}_{2}$ and $\mathrm{C}_{3} \mathrm{H}_{6}$. The striations in the buffer layer should be ignored because of excessive cycling of the acetylene flow rate. 
coating furnace. These were:

1. 24-cm-diam frit, 25 blind holes, as shown in Fig. 15;

2. 24-cm-diam frit, 13 blind holes;

3. 24-cm-diam frit, 9 blind holes; and

4. 13-cm-diam frit, 9 blind holes, located at the lower end of a cone, which flared to $24-\mathrm{cm}$ in diameter.

Eight Biso coating runs and one SiC run were sonducted. Designs 1 through 3 each performed very satisfactorily, with perhaps design 1 being slightly preferable. Type 4 was unsatisfactory; particle bed movement was more typical of that of a cone in that it tended toward slugging rather than uniform fluidization, and carbon coating efficiencies and coating properties were inferior to those obtained with the other three designs. All characterization data for the best Biso-coated particle batch indicate that the particles should have good irradiation performance. For this batch, the $\mathrm{BAF}_{0}$ averaged 1.033, and the defective fraction was $2 \times 10^{-5}$, as determined by the chlorine leach test. The defective fraction for the Sic-coated particles was $3 \times 10^{-5}$, and the SiC density was $3.206 \mathrm{~g} / \mathrm{cm}^{3}$; both valucs being very acceptable. All indications were that scale-up was feasible.

\section{CONCLUSIONS}

A comparison of equipment, process responses, and product quality showed that a new multiple-inlet porous-plate gas distributor is preferred over conical gas distributors for coating of HTGR fuel particles. Principal advantages of the porous plate distributor are simplicity, high assurance that particles will not drain from the coater during upset conditions, improved material accountablilty, and more uniform gas distribution, which leads to superior coating properties. Properties that are improved are particle sphericity, LTI isotropy, LTI thickness standard deviation, LTI microstructure, and LTI and SiC defective fraction. The new distributor appears ideally suited for scale-up to commercialsize coating furnaces. 


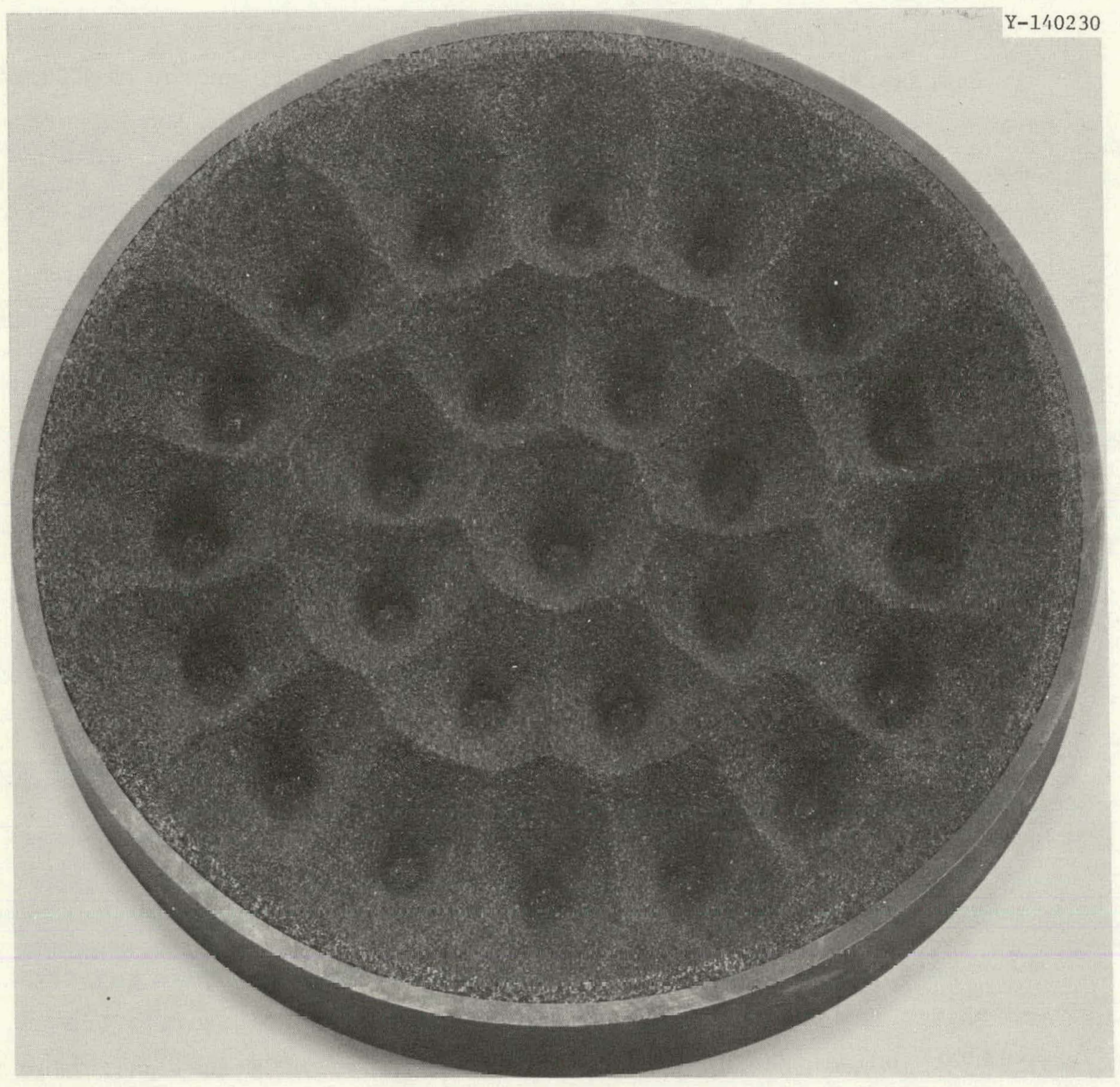

Fig. 15. Porous-Plate Gas Distributor, 24-cm-diam with 25 Blind Holes. 


\section{ACKNOWLEDGMENTS}

The assistance of M. K. Preston, R. R. Suchome1, and D. Kiplinger in the design, fabrication and cold checkout of equipment used in the 24-cm-diam coating furnace is greatly appreciated. Numerous members of the staff of General Atomic Company are thanked for their assistance in testing the 24-cm-diam frits. We are grateful to $\mathrm{C}$. E. DeVore and J. B. Flynn for their careful work during the coating of particles and measurement of coating thickness.

The manuscript was edited by Sigfred Peterson and prepared for submission for publication by Gail Golliher of the Metals and Ceramics Division Reports Office.

\section{REFERENCES}

1. R. B. Pratt, J. D. Sease, W. J. Pechin, and A. L. Lotts, "Pyrolytic Carbon Coating in an Engineering-Scale System," Nucl. App Z. 6(3): 241-55 (March 1969).

2. W. J. Lackey et al., "Microsphere Coating," Gas-Cooled Reactor and Thorium Utilization Progrom Annu. Progr. Rep. Sept. 30, 1971, ORNL-4760, pp . 45-52.

3. R. L. Pilloton, Fluidized-Bed Coating Apparatus, (to U.S. Atomic Energy Commission). U.S. Patent 3,889,631. August 27, 1968.

4. W. J. Lackey and J. D. Sease, Means for Effecting Fluidization in Pyrolytic Carbon Coating Processes (to U.S. Atomic Energy Commission). U.S. Patent 3,889,631. June 17, 1975.

5. P. R. Kasten et al., Assessment of the Thorizom Fuel Cycle in Power Reactors, ORNL/TM- 5565 (in press).

6. W. J. Lackey, W. H. Pechin, and J. D. Sease, "Measurement and Control of Shape of Fuel Particles for High-Temperature Gas-Cooled Reactors," Am. Cercom. Soc. BuZZ. 54(8): 718-24 (August 1975).

7. D. P. Stinton, W. J. Lackey, and D. R. Johnson, "Process Development," Gas-Cooled Reactor Programs Thorium Utilization Program Prog. Rep. Jan. 1, 1974 through June 30, 1975, ORNL-5128, pp. 158-65. 
8. D. W. Stevens, "Optical Anisotropy in Nearly Isotropic Pyrolytic Carbons," pp. 167-68, Eleventh Biennial Conference on Carbon, Gatlinburg, Tennessee (1973), Paper SS-3, CONF-730601.

9. D. E. LaValle, D. A. Costanzo, W. J. Lackey, and A. J. Caputo, The - Determination of the Defective Particle Fraction in HTGR Fuels, ORNL/TM-5483 (in press).

10. W. J. Lackey, J. D. Sease, D. A. Costanzo, and D. E. LaValle,"Improved Coating Process for High-Temperature Gas-Cooled Reactor Fuel," Trans. Am. Nucl. Soc. 22: 194-95 (November 1975).

11. W. J. Lackey, D. P. Stinton, L. E. Davis, and R. L. Beatty, "Crushing Strength of HTGR Fuel Particles," Nucl. 'l'echnol. 31(2): 191-201. (November 1976); ORNL/TM-5132. 
ORNL/TM-5731

Category

Distribution UC-77

\section{INTERNAL DISTRIBUTION}

1-2. Central Research Library

3. Document Reference Section

4-11. Laboratory Records Department

12. Laboratory Records, ORNL RC

13. ORNL Patent Office

14. P. Ange1.ini

15. B. J. Baxter

16. R. A. Bradley

17. C. R. Brinkman

18. A. J. Caputo

19. J. A. Carpenter

20. J. H. Coobs

21. D. Costanzo

22. J. E. Cunningham

23. F. C. Davis

24. J. H. DeVan

25. J. R. DiStefano

26. R. G. Donnelly

27. W. P. Eatherly

28. J. I. Federer

29. P. A. Haas

30. C. C. Haws

31. R. L. Hamner

32-34. M. R. Hi11

35. F. J. Homan

36. J. D. Jenkins

37. D. R. Johneon

38. M. J. Kania

39-40. P. R. Kasten

41. R. K. Kibbe

42-46. W. J. Lackey

47. D. E. LaValle

48. B. C. Leslie

49. T. B. Lindemer

50. A. L. Lotts.

51. J. E. Mack

52. W. R. Martin

53. R. W. McClung

54. H. E. McCoy
55. D. L. McElroy

56. C. J. McHargue

57. S. R. McNeany

58. C. S. Morgan

59. M. T. Morgan

60. K. J. Notz

61. A. P. Olsen

62. A. E. Pasto

63. P. Patriarca

64. R. L. Pearson

65. W. H. Pechin

66. H. Postma

67. J M Robbins

68. J. E. Rushton

69. T. F. Scanlan

70. A. C. Schaffhauser

71. J. L. Scott

72. J. D. Sease

73. J. H. Shaffer

74. J. W. Snider

75. J. 0. Stiegler

76-78. D. P. Stinton

79. R. R. Suchomel

80. V. J. Tennery

81. S. M. Tiegs

82. T. N. Tiegs

83. D. B. Trauger

84. J. E. Van Cleve

85. G. C. Wei

86. J. R. Weir, Jr.

87. R. G. Wymer

88. R. M. Young

89. C. S. Yust

90. H. M. Brister (consultant)

91. J. Moteff (consultant)

92. H. Palmour 1 II (consultant)

93. J. W. Prados (consultant)

94. N. E. Promisel (consultant)

95. D. F. Stein (consultant) 
EXTERNAL DISTRIBUTION

96-103. ERDA DIVISION OF NUCLEAR FUEL CYCLE AND PRODUCTION, Washington, D.C. 20545

Director

R. G. Bradley

W. S. Schieb

104-105. ERDA DIVISION OF REACTOR NUCLEAR RESEARCH AND APPLICATIONS, Washington, D.C. 20545

Director

106-107. ERDA IDAHO OPERATIONS OFFICE, P.O. Box 2108, Idaho Falls, ID 83401

C. E. Williams, Manager

Barry Smith

108. ERDA OFFICE OF PROGRAM MANAGEMENT, RESEARCH AND SPACE PROGRAMS, P.0. Box 81325, San Diego, CA 92138

J. B. Radcliffe

109. ERDA SAN FRANCISCO OPERATIONS OFFICE, 1333 Broadway, Wells Fargo Bldg., Oakland, CA 94612

R. D. Thorne, Manager

110-112. ERDA OAK RIDGE OPERATIONS OFFICE, P.O. Box E, Oak Ridge, TN 37830

Director, Research and Technical Support Division

Director, Reactor Division

F. E. Dearing, Reactor Division

113-176. ERDA TECHNICAL INFORMATION CENTER, P.O. Box 62, Oak Ridge, TN 37830

For distribution as shown in TID-4500 Distribution

Cálegory, UC-77 - Gas-Cooled Reactor Technology 